Brigham Young University Law School

BYU Law Digital Commons

Faculty Scholarship

$1-1-2009$

\title{
Medellin, the Alien Tort Statute, and the Domestic Status of International Law
}

David H. Moore

BYU Law, moored@law.byu.edu

Follow this and additional works at: https://digitalcommons.law.byu.edu/faculty_scholarship

Part of the International Law Commons, and the International Relations Commons

\section{Recommended Citation}

David H. Moore, Medellin, the Alien Tort Statute, and the Domestic Status of International Law, 50 VA. J. INT'L L. 485 (2009).

This Essay is brought to you for free and open access by BYU Law Digital Commons. It has been accepted for inclusion in Faculty Scholarship by an authorized administrator of BYU Law Digital Commons. For more information, please contact hunterlawlibrary@byu.edu. 


\title{
ESSAY
}

\section{Medellin, the Alien Tort Statute, and the Domestic Status of International Law}

\author{
DAVID H. MOORE*
}

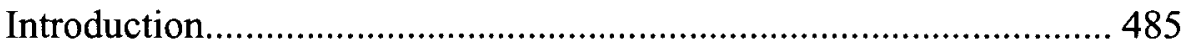

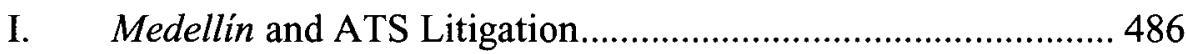

A. Treaty Claims Under the ATS .......................................... 486

B. Customary International Law Claims Under the ATS .... 494

II. Medellin and the Domestic Status of Customary

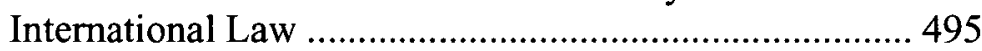

III. Medellin and Developing Uniformity for International Law .... 505

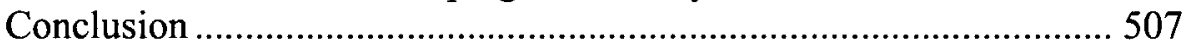

\section{INTRODUCTION}

International law derives from two primary sources: treaties and customary international law (CIL). ' The proper status of these two sources in the U.S. legal system is among the persistent debates in contemporary U.S. foreign relations law. In its past several terms, the U.S. Supreme Court has had the opportunity to provide fresh guidance on both debates. In Sosa v. Alvarez-Machain, the Court addressed a claim under

* Professor, J. Reuben Clark Law School, Brigham Young University. This Essay was conceived and begun during my time as a Visiting Professor at George Washington University Law School. I am grateful to George Washington Law for its generous financial support. I also thank Ben Teich for his helpful research assistance. This Essay is dedicated to Christian Garry Moore.

1. See Statute of the International Court of Justice art. 38, June 26, 1945, 59 Stat. 1031, 33 U.N.T.S. 993; RESTATEMENT (THIRD) OF FOREIGN RELATIONS LAW OF THE UNITED STATES $\S$ 102 (1987). 
the Alien Tort Statute (ATS) ${ }^{2}$ - an act passed by the First Congress in 1789-for violation of a CIL prohibition on arbitrary detention. ${ }^{3}$ In the course of addressing the import of the ATS, the Court also spoke to the domestic legal status of CIL. Much has been said about what Sosa means both for the future of ATS litigation and for the domestic role of $\mathrm{CIL}^{4}{ }^{4}$ This Essay does not reengage those questions.

Instead, this Essay focuses on the import of a more recent landmark decision: Medellin v. Texas. ${ }^{5}$ In Medellin, the Supreme Court addressed the domestic status of treaties in determining whether judgments of the International Court of Justice (ICJ) are judicially enforceable federal law. ${ }^{6}$ Medellin represents the Court's most important pronouncement on the domestic status of treaties in almost two hundred years. ${ }^{7}$ Commentators have begun to sort out what the decision means for treaties in domestic law, ${ }^{8}$ but the import of the decision for ATS litigation and for the domestic status of both CIL and international law more generally has been neglected by the literature. This Essay fills that void. Part I explains how Medellin narrows prospects for both treaty- and CIL-based claims under the ATS. Part II demonstrates that Medellin manifests the same separation of powers perspective as Sosa, thus supporting the revisionist position in the debate over the domestic status of CIL. Part III identifies how Medellin contributes to the development of a uniform doctrine governing the status of both treaties and CIL in the U.S. legal system.

\section{MEDELLÍN AND ATS LITIGATION}

\section{A. Treaty Claims Under the ATS}

The ATS vests federal district courts with "jurisdiction of any civil action by an alien for a tort only, committed in violation of the law of nations or a treaty of the United States."

2. 28 U.S.C. $\S 1350(2006)$.

3. Sosa v. Alvarez-Machain, 542 U.S. 692 (2004).

4. See, e.g., Curtis A. Bradley, Jack L. Goldsmith \& David H. Moore, Sosa, Customary International Law, and the Continuing Relevance of Erie, 120 HARV. L. REV. 869 (2007); David H. Moore, An Emerging Uniformity for International Law, 75 GEO. WASH. L. REV. 1 (2006).

5. 128 S. Ct. 1346 (2008).

6. Id.

7. See Curtis A. Bradley, Agora: Medellín: Intent, Presumptions, and Non-Self-Executing Treaties, 102 AM. J. INT'L L. 540, 550 (2008).

8. See, e.g., David Bederman et al., Agora: Medellin, 102 AM. J. INT'L L. 529 (2008).

9. 28 U.S.C. $\$ 1350(2006)$. 
practical context in which the debate over CIL's domestic status has occurred. The ATS and the Second Circuit decision that brought it out of obscurity have generated a significant number of lawsuits based on violations of international law. ${ }^{10}$ Most of these suits have dealt with violations of customary international law, but, because the ATS also provides jurisdiction over claims based on treaty violations, various treaty-based claims have also been raised.

For example, a dual citizen of Australia and the United Kingdom who was convicted of drug crimes in the United States sued the President of the United States and other U.S. officials, claiming that their failure to transfer him to the United Kingdom to complete his sentence violated the Council of Europe Convention on the Transfer of Sentenced Persons. " Finding no requirement to transfer in the treaty, the U.S. Court of Appeals for the District of Columbia Circuit rejected the claim. ${ }^{12}$ In another suit, the representative of a plane crash victim's estate sued the plane's manufacturer and operator. ${ }^{13}$ The representative alleged a wrongful death claim pursuant to the Convention for the Unification of Certain Rules Relating to International Transportation by Air (Warsaw Convention), premising jurisdiction on the ATS. ${ }^{14}$ Because "[t]he [Warsaw] Convention itself does not seek to outlaw accidents, crashes and other events causing death, injury or property loss," the court concluded that the ATS did not confer jurisdiction. ${ }^{15}$ As a final example, a Nigerian citizen convicted of drug crimes in the United States sued various U.S. officials under the ATS for failure to notify him of his right under the Vienna Convention on Consular Relations to contact the Nigerian consulate. ${ }^{16}$ The court dismissed the claim based on the plaintiff's failure to identify a tort committed in violation of the Vienna Convention and on his failure to carry his burden as to causation and damages. ${ }^{17}$ These decisions illustrate that there are numerous ob-

10. See Filartiga v. Pena-Irala, 630 F.2d 876 (2d Cir. 1980).

11. Bagguley v. Bush, 953 F.2d 660, 661, 663 (D.C. Cir. 1991) (per curiam); see also Council of Europe Convention on the Transfer of Sentenced Persons, Mar. 21, 1983, 35 U.S.T. 2867, 1496 U.N.T.S. 92.

12. Bagguley, 953 F.2d at 663.

13. Benjamins v. British European Airways, 572 F.2d 913, 914-15 (2d Cir. 1978).

14. Id. at 915-16; see also Convention for the Unification of Certain Rules Relating to International Transportation by Air, Oct. 12, 1929, 49 Stat. 3000, 137 L.N.T.S. 11.

15. Benjamins, 572 F.2d at 916.

16. Bieregu v. Ashcroft, 259 F. Supp. 2d 342, 345 (D.N.J. 2003); see also Vienna Convention on Consular Relations, Apr. 24, 1963, 21 U.S.T. 77, 596 U.N.T.S. 261.

17. Bieregu, 259 F. Supp. at 353-54. 
stacles to the successful prosecution of an ATS claim based on a treaty violation, including the requirement that the claim sound in tort. ${ }^{18}$

The Court's decision in Medellin further obstructs ATS claims that are grounded in treaty violations in at least two important ways. First, Medellin adopts a broad view of treaty non-self-execution. To understand the significance of this position, it is helpful to understand the academic debate against which the decision occurred.

Scholars have long challenged the constitutionality of the non-selfexecution doctrine, though these challenges have been a matter of degree. Despite sometimes broad language, scholars skeptical of non-selfexecution recognize that the doctrine may apply in limited circumstances. ${ }^{19}$ For example, Professor Carlos Vázquez asserts that "[c]oncluding that the Constitution gives treaties, once made, 'automatic' effect as domestic law requires only a reading of the Supremacy Clause, which declares 'all' treaties to be the 'supreme Law of the Land. ${ }^{\prime 20}$ At the same time, Vázquez accepts (in light of Supreme Court precedent) that treaty makers may overcome a presumption in favor of self-execution by providing a clear statement of non-self-execution; by crafting language that is vague or precatory; perhaps by entering a treaty that addresses only state-to-state obligations or that speaks to nonjudicial branches of the government, as an arms control treaty might; or by assuming obligations that violate Bill of Rights provisions or that require actions that are constitutionally committed to federal officials other than the treaty makers. ${ }^{21}$ Vázquez rejects the notion, however, that the treaty makers can successfully express an intent to create a non-selfexecuting agreement by something less than a clear statement. ${ }^{22}$

18. See, e.g., Xuncax v. Gramajo, 886 F. Supp. 162, 181 (D. Mass. 1995) (finding that, under the ATS, plaintiffs may bring claims "for torts committed in violation of a U.S. treaty," not for mere "violation of a U.S. treaty" (emphasis in original)); see also Sosa v. Alvarez-Machain, 542 U.S. 692, 712-14 (2004) (indicating that, in addition to the jurisdiction provided by the ATS, an ATS plaintiff needs a cause of action).

19. Cf. Carlos Manuel Vázquez, Laughing at Treaties, 99 COLUM. L. REV. 2154, 2174 (1999) (acknowledging that acceptance, based on Supreme Court caselaw, of some role for non-selfexecution "problematizes a literal interpretation of' the Supremacy Clause) (hereinafter Vázquez, Laughing at Treaties].

20. Id. at 2156-57; see also id. at $2169,2172$.

21. Id. at 2174-75, 2177-82, 2186-88; Carlos Manuel Vázquez, Treaties as Law of the Land: The Supremacy Clause and the Judicial Enforcement of Treaties, 122 HARV. L. REV. 599, 609, 630-31, 643, 694 (2008); Carlos Manuel Vázquez, Treaty-Based Rights and Remedies of Individuals, 92 CoLUM. L. REV. 1082, 1440 (1992) [hereinafter Vázquez, Treaty-Based Rights].

22. See Vázquez, Laughing at Treaties, supra note 19, at 2158 (attempting to reconcile Supreme Court non-self-execution cases with the text of the Supremacy Clause by "read[ing] the Supremacy Clause as adopting a default rule that treaties have the force of domestic law, a rule that may be reversed by the treatymakers through a clear statement in the treaty itself (or reserva- 
Professor Jordan Paust similarly asserts that " $[\mathrm{t}]$ he distinction found in certain cases between 'self-executing' and 'non-self-executing' treaties is a judicially invented notion that is patently inconsistent with [the] express language" of the Supremacy Clause. ${ }^{23}$ "[A]ll treaties, to the extent of their grants, guarantees or obligations, are self-executing." ${ }^{24}$ At the same time, Paust accepts that treaties may be non-self-executing if, "by their terms considered in context, [they] require domestic implementing legislation or seek to declare war on behalf of the United States." 25

Like Vázquez and Paust, Professor David Sloss reads the Supremacy Clause as "mandat[ing] automatic conversion of treaties [into domestic law] in most (but not all) cases." 26 Sloss acknowledges that "a treaty provision has no domestic legal effect in the absence of implementing legislation if it purports to accomplish something that, under our constitutional system, requires legislation approved by both Houses of Congress." 27 But, unlike Paust, Sloss perceives appropriation as such an act. ${ }^{28}$ Sloss also recognizes that a treaty may be non-self-executing if it is indeterminate or executory, creates only state-to-state obligations rather than obligations to private persons, or contravenes the constitutional rights of individuals or constitutionally-mandated principles of federalism. ${ }^{29}$ At the same time, Sloss concludes that, while treaty makers

tion thereto)").

23. Jordan J. Paust, International law as Law of the United States 67 (2d ed. 2003).

24. Id. at 75 ; see also id. at $69-70,72$ (discussing historical perspectives that support this position).

25. Id. at 80; see also id. at 70-72 (giving historical account of the domestic implementing legislation exception to self-execution); id. at 76-78 (discussing the war power exception). This does not mean, in Paust's view, that a treaty that "addresses an obligation of signatories to assure that any necessary implementing legislation is forthcoming" is necessarily non-self-executing. Id. at $91 \mathrm{n} .98$. The treaty may, for example, be non-self-executing in countries that do not recognize self-execution but self-executing in countries that do not require implementing legislation. Id. Similarly, this does not mean that Paust accepts unilateral declarations by the treaty makers that a treaty is non-self-executing. See Jordan J. Paust, Customary International Law and Human Rights Treaties Are Law in the United States, 20 MiCH. J. INT'L L. 301, 324-35 (1999).

26. David Sloss, Non-Self-Executing: Exposing a Constitutional Fallacy, 36 U.C. DAVIS L. REV. 1, 10 (2002) [hereinafter Sloss, Non-Self-Executing].

27. David Sloss, Schizophrenic Treaty Law, 43 TEX. INT'L L.J. 15, 17-18 (2007) [hereinafter Sloss, Schizophrenic]; see also Sloss, Non-Self-Executing, supra note 26, at 30-31.

28. Sloss, Schizophrenic, supra note 27, at 18 n.13; see also The Federalist Society Online Debate Series, Medellin v. Texas: Part I: Self-Execution (Mar. 28, 2008), http://www.fed-soc.org/ debates/dbtid.17/default.asp [hereinafter Federalist Society Debate] (featuring a debate between David Sloss, Ted Cruz, Nick Rozenkranz, and Edwin Williamson).

29. Sloss, Non-Self-Executing, supra note 26, at 28-31; see also Federalist Society Debate, supra note 28. 
may prevent treaty enforcement by plaintiffs, they may not prevent, by their mere intent, a treaty from becoming primary domestic law that may be invoked defensively if the treaty "create[s] primary international

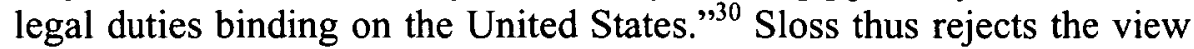
that, "if implementing legislation is not constitutionally required ... , the treaty makers . . . can preclude a treaty from having domestic legal status ... by manifesting their intention to do so."

Despite these varied academic efforts to narrow non-self-execution, the Medellin Court adopted a fairly expansive view of the doctrine. No member of the Court suggested that all treaties-or even all treaties not contemplating action that is constitutionally assigned to federal actors other than the treaty makers-are self-executing. In dissent, Justice Breyer endorsed the narrowest view of the non-self-execution doctrine, but even he recognized that treaties may be non-self-executing under certain circumstances. ${ }^{32}$ To him, the critical question (answered largely by the Supremacy Clause), ${ }^{33}$ was whether a treaty " 'addresses itself to the political ... department[s]' for further action or to 'the judicial department' for direct enforcement." ${ }^{34}$ To Justice Breyer, the answer to this question depends not on whether and how the treaty addresses the self-execution question, ${ }^{35}$ but on "practical, context-specific" criteria, including text, drafting history, subject matter, whether enforcement of the treaty would "engender constitutional controversy," and whether the treaty provides definite legal standards or requires the creation of a new cause of action. ${ }^{36}$ Under this approach, treaties addressing war and peace, for example, would be non-self-executing because they are addressed to the political branches. ${ }^{37}$

Justice Breyer thus acknowledges a role for non-self-execution, albeit (compared to the majority) a modest one. Moreover, given his focus on the objective, contextual character of the treaty (as one addressed to ei-

30. Sloss, Non-Self-Executing, supra note 26, at 46; see also id. at 43-70.

31. Sloss, Schizophrenic, supra note 27 , at 18 ; cf. Federalist Society Debate, supra note 28 (noting that the Constitution, not the treatymakers' intent, governs the question of whether a treaty is federal law).

32. Medellin v. Texas, 128 S. Ct. 1346, 1375-92 (2008) (Breyer, J., dissenting).

33. See id. at 1346, 1375-81, 1389; see also David H. Moore, Law(makers) of the Land: The Doctrine of Treaty Non-Self-Execution, 122 HARV. L. REV. F. 32, 43-44 (2009).

34. Medellin, $128 \mathrm{~S}$. Ct. at 1382 (Breyer, J., dissenting) (quoting Foster v. Neilson, 27 U.S. (2 Pet.) 253, 314 (1828)); see also id. at 1382-85, 1392.

35. See id. at 1380-82.

36. Id. at 1382; see also id. at 1385-89 (introducing additional considerations in answering the self-execution question in Medellin).

37. Id. at 1382, 1388. 
ther the political branches or the courts) and the multivariate nature of his analysis, Justice Breyer arguably gives the judiciary greater discretion than does the majority with regard to the domestic status of treaties, including the discretion to categorize the same treaty differently in different contexts. ${ }^{38}$

The majority found that a greater range of treaties would be non-selfexecuting. ${ }^{39}$ In particular, it endorsed the notion that a treaty may be non-self-executing if the treaty makers so intended. ${ }^{40}$ Moreover, while the Court did not explicitly announce a presumption that treaties are non-self-executing, its self-execution analysis includes considerations that will likely lead lower courts to classify treaties as non-selfexecuting more frequently. ${ }^{41}$ For example, the majority considered the practical consequences of concluding that ICJ judgments are unassailable federal law under the relevant treaties. ${ }^{42}$ Such a conclusion would threaten preemption of both state and federal law and create the possibility of domestically unreviewable ICJ orders that set aside domestic convictions and sentences. ${ }^{43}$ As discussed more fully below, ${ }^{44}$ this and other considerations on which the Court relied reflect a separation of powers vision under which courts should be reluctant to displace the primary domestic lawmakers and conductors of foreign affairs. ${ }^{45}$ This limitation on the judiciary's role means that fewer treaties will be deemed self-executing.

If a treaty is non-self-executing, it is, at a minimum, not judicially enforceable even in a court that possesses jurisdiction to hear treaty claims. ${ }^{46}$ As a result, violation of a non-self-executing treaty cannot give

38. See id. at $\mathbf{1 3 8 5}$ (suggesting that, pursuant to the same treaty obligations, some ICJ judgments might be self-executing and others not).

39. See id. at 1361-65 (majority opinion).

40. See infra text accompanying notes 98-103 (discussing the majority's emphasis on the treaty makers' intent).

41. See Moore, supra note 33, at 46

42. Medellin, $128 \mathrm{~S}$. Ct. at 1364 .

43. Id.; see also Transcript of Oral Argument, Medellin, 128 S. Ct. 1346 (2008) (No. 06-984)

44. See infra text accompanying notes $98-130$.

45. See Moore, supra note 33, at 45

46. See Restatement (ThIRD) OF Foreign Relations Law of the United States $\S 111(3)$ (1987). The conventional wisdom, as reflected in the Restatement of U.S. Foreign Relations Law, has been that "international agreements of the United States are law of the United States" and that non-self-executing agreements are judicially unenforceable absent congressional implementation. Id. § 111(1); see also id. § $111(3)$. Medellin introduces ambiguity regarding whether non-self-execution means something more: that a non-self-executing treaty is not domestic law. Compare, e.g., Medellin, $128 \mathrm{~S}$. Ct. at 1365 ("[T]he particular treaty obligations on which Medellin relies do not of their own force create domestic law."), and id. at 1369 ("[A] non-selfexecuting treaty can become domestic law only" by act of Congress.), with id. at $1356 \mathrm{n} .2$ ("What 
rise to an ATS claim. In Sosa, plaintiff Alvarez-Machain cited the International Covenant on Civil and Political Rights (ICCPR) to support his arbitrary detention claim. ${ }^{47}$ The Court noted that the ICCPR was "ratified ... on the express understanding that it was not self-executing and so did not itself create obligations enforceable in the federal courts." The Court thus concluded that the ICCPR could not "establish the relevant and applicable rule of international law" on which AlvarezMachain sought to rely. ${ }^{49}$ Because a non-self-executing treaty like the ICCPR cannot itself support an ATS claim, Medellin's broad notion of non-self-execution limits the range of potentially successful treaty claims under the ATS.

Medellin directly limits treaty-based ATS claims in another respect: Even when the relevant treaty is self-executing, a private plaintiff may not sue for a treaty violation in the absence of a cause of action. The Medellin Court endorsed a presumption, adopted by several circuits, "that '[i]nternational agreements, even those directly benefiting private persons, generally do not create private rights or provide for a private cause of action in domestic courts." 50 The dissent was similarly wary of judicial creation of treaty-based causes of action. ${ }^{51}$

The conclusion that treaties themselves do not generally create private rights of action would not obstruct treaty-based suits if the ATS created, or authorized federal courts to create, a cause of action for violations of international agreements. However, in Sosa, the Supreme Court concluded that the ATS is merely jurisdictional. ${ }^{52}$ There was no

\footnotetext{
we mean by 'self-executing' is that the treaty has automatic domestic effect as federal law upon ratification. Conversely, a 'non-self-executing' treaty does not by itself give rise to domestically enforceable federal law."), and id. at 1369 (describing execution as rendering a treaty "binding on domestic courts"). For further discussion of the meaning of non-self-execution, see Bradley, supra note 7, at 541,547-50 (discussing the ambiguity in Medellin regarding the effect of non-selfexecution); Curtis A. Bradley, Self-Execution and Treaty Duality, 2008 SUP. CT. R. 131, 174-75 (same); ABA/ASIL Joint Task Force on Treaties in U.S. Law, Report 10-12 (Mar. 16, 2009), available at http://www.asil.org/files/TreatiesTaskForceReport.pdf (same); Nicholas Quinn Rosenkranz, Non-Self-Execution and the Supreme Law of the Land 2 (2008) (unpublished manuscript, on file with author) ("The Medellin Court pretty clearly endorsed the position that nonself-executing treaties are not domestic rules of law at all."). But $c f$. Sosa v. Alvarez-Machain, 542 U.S. 692, 735 (2004) (indicating that when a treaty is "not self-executing" it does "not itself create obligations enforceable in the federal courts").

47. Sosa, 542 U.S. at 734.

48. Id. at 735 .

49. Id.

50. Medellin, 128 S. Ct. at 1357 n.3 (quoting RESTATEMENT (THIRD) OF ForeIGN RELATIONS LAW OF THE UNITED STATES $§ 907 \mathrm{cmt}$. a (1987)).

51. See id. at 1382, 1388 (Breyer, J., dissenting).

52. Sosa, 542 U.S. at $713-14$.
} 
suggestion that the Court's conclusion would be different for the portion of the ATS addressing jurisdiction over treaty claims. The treaty provision of the ATS is but a clause in the same sentence addressing jurisdiction over CIL-based claims. ${ }^{53}$ Furthermore, the reasons the Court gave for finding the ATS to be jurisdictional apply equally in the treaty context: namely, (a) that the ATS originally "gave the district courts 'cognizance' of certain causes of action, and the term bespoke a grant of jurisdiction, not power to mold substantive law"; (b) that the ATS was part of the Judiciary Act of 1789, which otherwise solely addressed jurisdiction; and (c) that the drafters and enactors of the ATS understood "the distinction between jurisdiction and cause of action." 54

The jurisdictional finding in Sosa did not completely preclude federal courts from creating causes of action for some international law violations. After holding that the ATS was jurisdictional, the Court found that the intent of the enacting Congress gave rise to limited, residual authority for the federal courts to recognize causes of action based on CIL. ${ }^{55}$ The Court reasoned that the First Congress expected that certain claims based on the law of nations, "admitting of a judicial remedy," could be prosecuted in the federal courts pursuant to ATS jurisdiction. ${ }^{56}$ But the claims were few, given the recognition at the time that "offenses against [the] law [of nations] are principally incident to whole states or nations,' and not individuals seeking relief in court." ${ }^{57}$ Presumably, Congress also thought that treaties - to the extent they transcended state-to-state rights and duties-would be enforced under the ATS only if the treaties themselves created a private right of action..$^{58}$ Medellin, of course, endorses the presumption that treaties do not create rights of action. ${ }^{59}$ Plaintiffs seeking to rectify treaty violations through the ATS must either overcome this presumption or identify a cause of action in some other source. ${ }^{60}$ The difficulty of establishing a cause of action, in

53. See 28 U.S.C. $\S 1350$ (2006).

54. Sosa, 542 U.S. at 713 .

55. See id. at 724-25.

56. Id. at 715; see also id. at 719-20.

57. Id. at 720 (quoting 4 WILliam BLACKSTONE, COMMENTARIES *68).

58. As "there is no record even of debate on the" ATS, one can only surmise what Congress intended based on the historical context and motivation for enacting the statute. Sosa, 542 U.S. at 718.

59. Medellín v. Texas, 128 S. Ct. 1346, 1357 n.3 (2008).

60. Private rights of action to address treaty violations might be available through other vehicles, such as 42 U.S.C. $\S 1983$ (2006), the Administrative Procedure Act, 5 U.S.C. $\S 702$ (2006), or habeas review, 28 U.S.C. $\S \S 2254,2255$ (2006), though claims under these vehicles would not need to rely on the ATS's jurisdictional grant. See Vázquez, Laughing at Treaties, supra note 19, at 2182-83, 2196-98; Vázquez, Treaty-Based Rights, supra note 21, at 1134, $1143-$ 
conjunction with the requirement that the treaty violated be selfexecuting, significantly hinders treaty-based ATS claims.

\section{B. Customary International Law Claims Under the ATS}

As treaty claims under the ATS are relatively rare and face significant hurdles, Medellin's limitations on such claims have a limited practical impact. However, Medellin's approach to treaty self-execution is also relevant to ATS claims based on CIL. These claims are far more common than claims based on treaties. For example, in the seminal case of Kadic v. Karadzic, citizens of Bosnia and Herzegovina successfully stated individual-capacity claims of genocide and war crimes against the defendant, the commander of Bosnian-Serb military forces and "the President of a three-man presidency of [a] self-proclaimed Bosnian-Serb republic within Bosnia-Herzegovina."61 Similarly, in the significant case of Doe v. Unocal, Burmese villagers sued various oil companies for "directly or indirectly subject[ing] the villagers to forced labor, murder, rape, and torture" in the construction of a gas pipeline in Burma. ${ }^{62}$ Other suits against corporations have addressed, inter alia, violations of the rights to life, health, and sustainable development caused by intraterritorial pollution from mining-related activities, ${ }^{63}$ and violations based on the administration of experimental medicine without obtaining informed consent. ${ }^{64}$ Aliens have also sued U.S. officials and contractors for violations of CIL in the conduct of the war on terrorism. Plaintiffs have sued, for example, for prolonged arbitrary detention and cruel, inhuman, and degrading treatment resulting from the Central Intelligence Agency's extraordinary rendition practices. ${ }^{65}$

Sosa v. Alvarez-Machain also involved a CIL-based claim. The plaintiff, Alvarez-Machain, was kidnapped in Mexico by Mexican nationals pursuant to a plan approved by the U.S. Drug Enforcement Agency. ${ }^{66}$ He then sued under the ATS, claiming (as the Court perceived it) ${ }^{67}$ vi-

54; John T. Parry, A Primer on Treaties and $\$ 1983$ After Medellin v. Texas, 13 LEWIS \& CLARK L. REV. 35 (2009).

61. Kadic v. Karadzic, 70 F.3d 232, 237 (2d Cir. 1995); see id. at 241-43.

62. Doe I v. Unocal Corp., 395 F.3d 932, 936 (9th Cir. 2002), rehearing en banc granted, 395 F.3d 978 (9th Cir. 2003), appeal dismissed and district court opinion vacated, 403 F.3d 708 (9th Cir. 2005).

63. See, e.g., Flores v. Southern Peru Copper Corp., 414 F.3d 233, 237-38 (2d Cir. 2003).

64. See Abdullahi v. Pfizer, Inc., 77 F. App'x 48, 50-51 (2d Cir. 2003).

65. El-Masri v. United States, 479 F.3d 296, 299-301 (4th Cir. 2007).

66. Sosa v. Alvarez-Machain, 542 U.S. 692, 698 (2004).

67. See Ralph G. Steinhardt, Laying One Bankrupt Critique to Rest: Sosa v. Alvarez-Machain and the Future of International Human Rights Litigation in U.S. Courts, 57 VAND. L. REV. 2241, 
olation of a CIL norm against " "arbitrary' detention defined as officially sanctioned action exceeding positive authorization to detain under the domestic law of some government." ${ }^{168}$ Alvarez-Machain relied on the ICCPR as evidence that CIL embraced the alleged norm. ${ }^{69}$ The Court, however, concluded that, even if Alvarez-Machain's assertion were "an accurate reading of the [ICCPR]," he had mustered "little authority that a rule so broad has the status of a binding customary norm today." Court thus discounted the evidentiary value of non-self-executing treaties in the identification of actionable norms of CIL. ${ }^{71}$

Medellin took the next step toward limiting CIL-based ATS claims. ${ }^{72}$ By giving the doctrine of non-self-execution a broader scope than its critics would afford ${ }^{73}$ the Court increased the number of treaties that might be classified as non-self-executing. Because Sosa discounted the evidentiary value of non-self-executing treaties in establishing CIL claims, Medellin thinned the evidence available to plaintiffs seeking to recover under the ATS for violations of CIL.

\section{MEDELLIN AND THE DOMESTIC STATUS OF CUSTOMARY INTERNATIONAL LAW}

In addition to limiting ATS claims based on treaty and CIL violations, Medellin bears on the broader and more significant question of CIL's domestic legal status. This issue has split scholars into two factions: a modernist camp and a revisionist camp. ${ }^{74}$ Modernists maintain that CIL is federal common law that federal courts may apply in the absence of positive authorization; revisionists argue that either the politi-

2253, 2281-82 (2004) (noting the Court's cramped conception of Alvarez-Machain's claim).

68. Sosa, 542 U.S. at 736.

69. Id. at $734-35$.

70. Id.

71. See Bradley, Goldsmith \& Moore, supra note 4, at 899-901. The Court's position on the evidentiary value of non-self-executing treaties was not without ambiguity. See id. at 901 .

72. See Medellín v. Texas, $128 \mathrm{~S}$. Ct. 1346 (2008).

73. See infra text accompanying notes $98-130$.

74. The debate between the camps was largely framed by Curtis A. Bradley \& Jack L. Goldsmith, Customary International Law as Federal Common Law: A Critique of the Modern Position, 110 HARV. L. REV. 815 (1997), and Harold Hongju Koh, Is International Law Really State Law?, 111 HARV. L. REV. 1824 (1998), though many entered the fray. See, e.g., Ryan Goodman \& Derek Jinks, Filartiga's Firm Footing: International Human Rights and Federal Common Law, 66 FORDHAM L. REV. 463 (1997); Gerald L. Neuman, Sense and Nonsense About Customary International Law, 66 FORDHAM L. REV. 371 (1997); Beth Stephens, The Law of Our Land: Customary International Law as Federal Law After Erie, 66 FORDHAM L. REV. 393 (1997). 
cal branches or the Constitution must authorize federal judicial reliance on CIL as a domestic rule of decision. ${ }^{75}$ Although both camps purported to find an endorsement of their position in Sosa ${ }^{76}$ Medellin tips the scale toward the revisionist position by displaying the same separation of powers vision that revisionists perceived in Sosa.

The separation of powers perspective underlying Sosa is apparent in the considerations that the Sosa Court identified to guide lower courts in recognizing causes of action based on CIL ${ }^{77}$ Primary among these considerations was the intent of the political branches. ${ }^{78}$ It was the intent of the First Congress that led to recognition of some residual judicial authority to recognize CIL-based claims, ${ }^{79}$ just as it was the First Congress's intent (as well as the absence of broader intent in subsequent Congresses) that limited the scope of that residual authority. Thus, federal courts may only recognize claims for violations of customary international law norms as specifically defined and widely accepted as the CIL norms Congress presumably had in mind in enacting the ATS. ${ }^{80}$

The requirements of specific definition and wide acceptance, grounded as they are in congressional intent, reflect a separation of powers vision in which authority to make domestic law based on CIL derives from the primary federal lawmaker-Congress. The requirements confirm that vision by communicating the sense that federal courts should not fill otherwise vague CIL norms with specific content, particularly where doing so would have significant foreign policy implications or would commit the United States to CIL obligations that other states have not assumed. ${ }^{81}$

Although the specific-definition and mutuality requirements played the dominant role in Sosa, the Supreme Court's separation of powers vision appeared in other considerations as well. In connection with the

75. See, e.g., Bradley \& Goldsmith, supra note 74, at 816-17, 870 .

76. Compare, e.g., Bradley, Goldsmith \& Moore, supra note 4, at 873, 902-10, and Moore, supra note 4, at 8, 48-49, with Martin S. Flaherty, The Future and Past of U.S. Foreign Relations Law, 67 LAW \& CONTEMP. PROBS. 169, 173 (2004), and Harold Hongju Koh, The 2004 Term: The Supreme Court Meets International Law, 12 TULSA J. COMP. \& INT'L L. 1, 12-13 (2004). Others concluded that Sosa said much less than either side claimed. See Julian Ku, A No Decision: Sosa v. Alvarez-Machain and the Debate Over the Domestic Status of Customary International Law, 101 AM. SOC'Y INT'L L. PROC. 267, 267-69 (2007).

77. For a more detailed discussion of these considerations, see Moore, supra note 4, at 31-38.

78. See Sosa v. Alvarez-Machain, 542 U.S. 692, 712-25 (2004).

79. See id. at 714-25; see also id. at 744 (Scalia, J., concurring in part) ("The Court would apparently find authorization [for continued judicial recognition of some CIL-based claims] in the understanding of the Congress that enacted the ATS ....").

80. See id. at $725,731-32$ (majority opinion).

81. See infra text accompanying notes 86-96. 
specific-definition requirement, the Court instructed lower courts to ponder the practical consequences of recognizing a particular cause of action. ${ }^{82}$ Recognition of Alvarez-Machain's claim of "officially sanctioned detention exceeding positive authorization to detain under the domestic law of some government" would open federal courts to, inter alia, claims "for any arrest, anywhere in the world, unauthorized by the law of the jurisdiction in which it took place. ${ }^{283}$ Federal judicial authority is too circumscribed to support generation of such consequences. Further, the Court counseled "deference to the political branches" in appropriate cases, such as class action litigation against companies that transacted with the South African apartheid regime-litigation that South Africa and the United States agreed would undercut the South African government's policy of dealing with apartheid through truth and reconciliation. ${ }^{84}$ Finally, the Court noted that it would recognize an international law requirement of exhaustion of remedies in certain cases. ${ }^{85}$ These additional considerations reveal a separation of powers vision that leaves primary responsibility for lawmaking and foreign affairs to the political branches rather than the courts.

This separation of powers vision is also manifest in the Sosa Court's comments on the limited role of the federal judiciary-comments that motivated, at a minimum, the specific-definition and mutuality considerations discussed above. ${ }^{86}$ As the Court explained, "there are good reasons for a restrained conception of the discretion a federal court should exercise in considering a new cause of action" based on CIL. ${ }^{87}$ It is now generally understood that common law is made, not found or discovered, as was thought under the Swift v. Tyson regime. ${ }^{88}$ In light of Erie

82. Sosa, 542 U.S. at $732-33,736-37$.

83. Id. at 736 ; see also id. at 737.

84. Id. at $733 \mathrm{n}$. 21 . The Second Circuit allowed consolidated apartheid litigation to go forward on the ground that the ATS accommodated claims of aiding and abetting liability. Khulumani v. Barclay Nat'l Bank Ltd., 504 F.3d 254, 260 (2d Cir. 2007) (per curiam). The court of appeals left to the district court the task of determining whether deference to the executive required dismissal. Id. at 260-61. Interestingly, on petition for certiorari, recusals left the Supreme Court without the required quorum of six, causing the Court to affirm the Second Circuit's decision pursuant to 28 U.S.C. $\$ 2109$ (2006). See Am. Isuzu Motors, Inc. v. Ntsebeza, 128 S. Ct. 2424 (2008). On remand, the district court concluded that deference to the executive did not require dismissal of plaintiffs' aiding and abetting claims. See In re S. African Apartheid Litig., $617 \mathrm{~F}$. Supp. 2d 228, 284 (S.D.N.Y. 2009).

85. Sosa, 542 U.S. at 733 n.21.

86. See id. at $725,727-28$.

87. Id. at 725 .

88. 41 U.S. (16 Pet.) 1, 7 (1842); see also Sosa, 542 U.S. at 726. 
Railroad Co. v. Tompkins, ${ }^{89}$ federal courts have a limited role in making common law. Federal courts generally "look for legislative guidance before exercising innovative authority over substantive law"90 and leave the "decision to create a private right of action . . . to legislative judgment in the great majority of cases." extends to cases involving CIL, although "the absence of congressional action addressing private rights of action under an international norm is more equivocal than its failure to provide such a right when it creates a statute." ${ }^{92}$

Not only should the federal courts hesitate to infringe on the political branches' lawmaking authority, they should also be "wary of impinging on the discretion of the Legislative and Executive Branches in managing foreign affairs." ${ }^{\text {"93 }}$ Making common law based on CIL risks such impingement because CIL-based claims can involve U.S. courts in the sensitive task of assessing the international legality of foreign sovereigns' actions toward their own citizens. ${ }^{94} \mathrm{Had}$ Congress authorized broad recognition of common law claims based on CIL, the Court's concerns for overstepping the federal judiciary's role in lawmaking and foreign affairs would be mitigated. ${ }^{95}$ But in the ATS context there is "no congressional mandate to seek out and define new and debatable violations of the law of nations, and modern indications of congressional understanding of the judicial role in the field have not affirmatively encouraged greater judicial creativity." 96 Thus, in keeping with Sosa's separation of powers vision, federal courts should be wary of recognizing ATS claims based on CIL.

Medellin is grounded in the same view of separation of powers. The Medellin Court was required to consider whether U.S. treaty obligations with regard to the International Court of Justice were self-executing in order to decide if the ICJ's decision in Case Concerning Avena and Other Mexican Nationals ${ }^{97}$ was automatically enforceable federal law.

89. 304 U.S. $64,79-80$ (1938).

90. Sosa, 542 U.S. at 726 .

91. Id. at 727 .

92. Id.

93. Id.

94. Id.

95. Consistent with this principle, the Sosa Court "welcome[d] any congressional guidance in exercising jurisdiction with such obvious potential to affect foreign relations." Id. at 731 .

96. Id. at 728 .

97. Case Concerning Avena and Other Mexican Nationals (Mex. v. U.S.), 2004 I.C.J. 12 (Mar. 31). The ICJ held in Avena that certain Mexican nationals, including Medellin, who were arrested and convicted in the United States without being informed of their Vienna Convention 
The factors that informed the Court's self-execution analysis disclose a separation of powers perspective similar to the one underlying Sosa.

Although the Court's opinion is not without ambiguity, the primary consideration guiding the Court's self-execution analysis is the intent of the political branches-specifically, the intent of the President and Senate that adopted the treaty obligation. ${ }^{98}$ After a lengthy analysis, the Court concluded that "[n]othing in the text, background, negotiating and drafting history, or practice among signatory nations suggests that the President or Senate intended the improbable result of giving the judgments of an international tribunal a higher status than that enjoyed by 'many of our most fundamental constitutional protections." "99 As in So$s a$, the Court indicated in Medellin that the political branches control the extent to which treaties are judicially enforceable domestic law.

In ascertaining the intent of the political branches, the Court first relied on the text of the relevant treaties: the UN Charter, the Statute of the ICJ, and the Optional Protocol to the Vienna Convention on Consular Relations (Protocol).$^{100}$ The Protocol, the Court reasoned, addressed jurisdiction, not the binding effect of ICJ judgments. ${ }^{101}$ "The obligation ... to comply with ICJ judgments" was derived from the UN Char-

right to notify their consulate were entitled to review and reconsideration of their convictions and sentences. See id. at 73.

98. See Medellin v. Texas, $128 \mathrm{~S}$. Ct. 1346, 1356 (2008) (stating that a treaty is self-executing if it "conveys an intention that it be self-executing and is ratified on those terms") (internal quotation marks omitted) (quoting Igartua-De La Rosa v. United States, 417 F.3d 145, 150 (1st Cir. 2005) (en banc)); id. at 1358 (finding that the UN Charter obligation under which each state "undertakes to comply" with ICJ decisions does not "indicate that the Senate that ratified the U.N. Charter intended to vest ICJ decisions with immediate legal effect in domestic courts") (emphasis omitted); id. at 1359 (reasoning - based on statements from the executive-that "the President and Senate were undoubtedly aware" in ratifying the UN Charter that the United States could veto Security Council attempts to enforce ICJ judgments against the United States); $i d$. at 1360 ("[T] he Executive and ratifying Senate" always regarded a Security Council veto "as an option ... during and after consideration of the U.N. Charter, Optional Protocol, and ICJ Statute .... [T] here is no reason to believe that the President and Senate signed up for" a regime of automatic enforcement in domestic courts that would undermine the veto option.); id. at 1362 (defending reliance on treaties' text on the grounds that the text "is ... what the Senate looks to in deciding whether to approve the treaty"); id. at 1364 ("[W]e have held treaties to be self-executing when the textual provisions indicate that the President and Senate intended for the agreement to have domestic effect."); id. at 1366 ("Our cases simply require courts to decide whether a treaty's terms reflect a determination by the President who negotiated it and the Senate that confirmed it that the treaty has domestic effect."). See also Bradley, supra note 7, at 543-45. But cf. Medellin, $128 \mathrm{~S}$. Ct. at 1362 (interpreting the Supreme Court's early self-execution decision in United States v. Percheman, 32 U.S. (7 Pet.) 51 (1833), as relying on "the parties' intent" rather than the U.S. treaty makers' intent).

99. Medellin, $128 \mathrm{~S}$. Ct. at 1367.

100. Id. at 1357; see also id. at 1364-65.

101. Id. at 1358 . 
ter, which requires that member states "undertake[] to comply with" ICJ decisions in cases to which they are party. ${ }^{102}$ This language, with its absence of specific imperatives, contemplates future steps to comply with ICJ judgments rather than an intent on behalf of the treaty makers to render such judgments immediately enforceable in U.S. courts. ${ }^{103}$

What sort of language would be required to establish self-execution? Justice Breyer wrote in his dissenting opinion that the majority imposed a clear-statement obligation on treaty makers who wish to produce a self-executing treaty. ${ }^{104}$ There is certainly language in the majority opinion to support such a reading. Citing "general principles of interpretation," the Court explained "that "absent a clear and express statement to the contrary, the procedural rules of the forum State govern the implementation of the treaty in that State." "105 Similarly, the Court stated that the executive may create a self-executing treaty "by ensuring that [the treaty] contains language plainly providing for domestic enforceability," but "[o]nce a treaty is ratified without provisions clearly according it domestic effect," Congress must decide whether the treaty will have domestic effect. ${ }^{106}$ At the same time, the Court rejected "the dissent's suggestion ... [that its] approach [or its] cases require that a treaty provide for self-execution in so many talismanic words." 107 To the extent the dissent is correct that the majority imposed a clear statement rule or at least favored a clear statement, the Court certainly narrowed the judicial role in treaty enforcement. Even if the Court adopted something less than a clear statement requirement, its attempt to discern the treaty makers' intent from the treaty text places control over the self-execution question principally in the political branches.

In addition to its reliance on the text of the treaties, the Court considered alternatives to enforcement in U.S. courts. ${ }^{108}$ The UN Charter provides for referral to the Security Council in the event of noncompliance with an ICJ judgment. ${ }^{109}$ The existence of an alternative remedy

102. Id. (emphasis omitted) (quoting U.N. Charter art. 94, para. 1).

103. Id. at 1358; see also id. at 1373 (Stevens, J., concurring in the judgment) ("[T]he words 'undertakes to comply' . . . are most naturally read as a promise to take additional steps to enforce ICJ judgments.").

104. Id. at 1380-82 (Breyer, J., dissenting).

105. Id. at 1363 (majority opinion) (quoting Sanchez-Llamas v. Oregon, 548 U.S. 331, 351 (2006)).

106. Id. at 1369 .

107. Id. at 1366 .

108. Id. at 1359 .

109. Id.; see U.N. Charter art. 94, para. 2. 
counsels against automatic judicial enforcement, ${ }^{110}$ particularly when the remedy provided is contingent and diplomatic, not judicial. ${ }^{111}$ The existence of such a remedy is especially significant where the President and Senate, in ratifying the relevant treaties, fully understood that "the United States retained the unqualified right to" veto attempts at enforcement through the Security Council, leaving "no reason to believe that" they signed up for domestic judicial enforcement that would undermine the veto option. ${ }^{112}$

The Court's reliance on the Security Council alternative to judicial enforcement manifests a desire to avoid undermining the political branches' foreign policy discretion. The UN Charter acknowledges that states will have to make decisions regarding compliance. ${ }^{113}$ The Court recognized that the political branches, not the courts, should make the delicate decision "whether and how to comply with an ICJ judgment," particularly since the Constitution commits the conduct of U.S. foreign affairs to the President and Congress. ${ }^{114}$ The Court was also sensitive to the political branches' lead role in foreign affairs in recognizing that the executive's consistent interpretation of the relevant treaty obligations as non-self-executing "is entitled to great weight."

The Court further protected the political branches' foreign affairs authority by rejecting Justice Breyer's expansive view of self-execution. According to the majority, Justice Breyer's multivariate approach would permit the judiciary to "pick and choose which [treaties] shall be binding United States law . . . and which shall not." 116 Under this analysis, "the same treaty sometimes gives rise to United States law and sometimes does not, ... depending on an ad hoc judicial assessment." 117 The Constitution's assignment of the power to create treaties, including treaties that qualify as federal law, to the political branches excludes the role Justice Breyer assigns to the judiciary. ${ }^{118}$ Justice Breyer's approach "is tantamount to vesting with the judiciary the power not only to interpret but also to create the law." 119

110. See Moore, supra note 4 , at $45-46$.

111. Medellin, $128 \mathrm{~S}$. Ct. at 1359.

112. Id. at $1359-60$.

113. Id. at 1360; see also U.N. Charter art. 27, para. 3; id. art. 94, para. 2.

114. Medellin, $128 \mathrm{~S}$. Ct. at 1360.

115. Id. at 1361 (quoting Sumitomo Shoji America, Inc. v. Avagliano, 457 U.S. 176, 184-85 (1982)).

116. Id. at 1362 .

117. Id.

118. Id

119. Id. at 1363 . 
Moreover, Justice Breyer's approach risks negative foreign policy consequences, as the United States and other countries would be hesitant to "enter into treaties that are sometimes enforceable and sometimes not," treaties that would, in essence, give "a blank check to the judiciary." 20 Justice Breyer countered that the Court's approach would have serious foreign policy consequences, as it would call into question compromissary clauses in many existing U.S. treaties. ${ }^{121}$ The Court, however, dismissed this argument on four grounds: (a) other compromissary clauses may produce ICJ judgments with immediate domestic effect; (b) those compromissary clauses that do not afford ICJ judgments immediate domestic effect still give rise to international obligations that may generate diplomatic remedies; (c) the underlying treaty on which the judgment was based may be self-executing; and (d) Congress is competent to execute non-self-executing obligations. ${ }^{122}$ In short, the Court's concern for both the foreign affairs discretion of the political branches and U.S. relations with other countries supported the conclusion that the relevant treaty obligations were not self-executing.

The Court also concluded that the non-self-executing character of the treaty obligations at issue in Medellin was "confirmed by the "postratification understanding' of signatory nations." 123 "[T] he lack of any basis for supposing that any other country would treat ICJ judgments as directly enforceable as a matter of their domestic law" led the Court to conclude "that the treaty should not be so viewed in our courts." 124 Because other nations had not assumed such an obligation, the Court concluded that it should not assume a unilateral obligation to that effect on behalf of the United States. ${ }^{125}$

The potential consequences of concluding that the treaty obligations in Medellin were self-executing likewise supported the Court's non-selfexecution holding. If ICJ judgments were unassailable federal law, they could not only override both state and federal law, but also prevent federal or state courts from evaluating ICJ orders that went so far as to "annul criminal convictions and sentences, for any reason deemed suffi-

120. Id. at 1362 .

121. Id. at $1387-88$ (Breyer, J., dissenting).

122. Id. at 1365-66 (majority opinion).

123. Id. at 1363 .

124. Id.

125. See id. The Court also considered evidence that the ICJ itself does not "view[] its judgments as automatically enforceable in the domestic courts of signatory nations." $1 d$. at $1361 \mathrm{n} .9$. However, this consideration was mentioned only in a footnote. 
cient by the ICJ." 126 Even the dissent was unwilling to treat all ICJ judgments - for example, "politically sensitive judgments"-as selfexecuting. ${ }^{127}$

Like the analysis in Sosa, Medellin's self-execution analysis reflects a limited role for the judiciary in domestic lawmaking and foreign affairs. The Medellin Court explicitly relied on the Constitution's delegation of the conduct of foreign affairs to the political departments in concluding that the relevant treaties did not give rise to self-executing obliobligations. ${ }^{128}$ In response to Justice Breyer's dissent, the Court criticized a conception of the self-execution doctrine that gave too much discretion to the judiciary at the expense of the political branches. ${ }^{129}$ The Court concluded that Congress and the executive-not the federal judiciary-should have "the primary role in deciding when and how international agreements will be enforced." 130

The Medellin Court's reliance on the separation of lawmaking and foreign affairs powers, paralleling the Court's vision in Sosa, lends support to the revisionist perspective on CIL's domestic legal status. $\mathrm{Me}$ dellin also supports the revisionist viewpoint in at least two other ways.

First, one might attack the revisionist reading of Sosa by arguing that Sosa perceives CIL as a body of U.S. law and deals solely with whether CIL may be fitted to a cause of action. ${ }^{131}$ I, along with Professors Jack Goldsmith and Curtis Bradley, have previously explained why Sosa should be read as addressing the incorporation of CIL into U.S. law. ${ }^{132}$ Medellin lends additional support to the dualist position that CIL is outside U.S. law, not merely a body of U.S. law that may not readily be fitted to a cause of action. The Medellin Court repeatedly suggested that non-self-executing treaties are not domestic law, rather than domestic law that is merely judicially unenforceable. ${ }^{133}$ Similarly, Justice Breyer

126. Id. at 1364 .

127. Id.

128. Id. at 1360 .

129. See supra text accompanying notes $39-45$.

130. Medellin, $128 \mathrm{~S}$. Ct. at 1363; see also id. at 1364 (reasoning that if Congress intended that "some politically sensitive [ICJ] judgments" be non-self-executing, "the judiciary should [not be the branch of government to] decide which judgments are politically sensitive and which are not"). But cf. id. at 1365 (asserting that whether a treaty is self-executing "is, of course, a matter for this Court to decide").

131. Bradley, Goldsmith \& Moore, supra note 4, at 909.

132. Id.

133. See, e.g., Medellin, $128 \mathrm{~S}$. Ct. at 1356 ("[W]hile treaties 'may comprise international commitments ... they are not domestic law unless Congress has either enacted implementing statutes or the treaty itself conveys an intention that it be "self-executing" and is ratified on these terms." (quoting Igartua-De la Rosa v. United States, 417 F.3d 145, 150 (1st Cir. 2005) (en 
explained that, as a result of the Supremacy Clause, "treaty provisions that bind the United States may . . . also enter domestic law without further congressional action and automatically bind the States and courts as well." ${ }^{134}$ While these references may merely be shorthand for describing domestic law that is not judicially enforceable, they may also suggest that the Court intuits that international law is a body of law outside the domestic system.

Second, even if the Court perceives non-self-executing treaties and CIL as some form of judicially unenforceable domestic law, it appears that at least one of its members contemplates a more limited role for CIL than for treaties. Justice Breyer-one of the Court's more transnationalist justices-did not reject non-self-execution in Medellin, but rather perceived it as having a more limited application than the majority allowed. Under Justice Breyer's approach, more treaties, including the treaties at issue in Medellin, ${ }^{135}$ would be self-executing and therefore enforceable by U.S. courts. By contrast, in his concurrence in Sosa, Justice Breyer argued for a limit on the incorporation of CIL beyond the limits the majority recognized. ${ }^{136}$ While endorsing considerations of specific definition, wide acceptance, deference to the executive, and alternative means of enforcement, Justice Breyer was also concerned that "the exercise of jurisdiction under the ATS ... [be] consistent with those notions of comity that lead each nation to respect the sovereign rights of other nations by limiting the reach of its laws and their enforcement." ${ }^{137}$ Consequently, in deciding whether to exercise jurisdic-

banc))); id. at 1365 ("[T] he particular treaty obligations on which Medellin relies do not of their own force create domestic law."); $i d$. at 1365 (noting that international judgments may be valuable even if they do "not automatically become domestic law"); id. at 1367 ("In sum, while the ICJ's judgment in Avena creates an international law obligation on the part of the United States, it does not of its own force constitute binding federal law that pre-empts state [law]."); id. at 1369 ("[A] non-self-executing treaty can become domestic law only [by act of Congress]."); id. at 1370 (referring to "the President's asserted authority to create domestic law pursuant to a non-selfexecuting treaty" and to "transforming an international obligation into domestic law"); id. at 1371 (referring both to giving "the ICJ's decision in Avena the force of domestic law" and to creating domestic law); id. at 1372 ("[T] he Avena judgment is not domestic law."); id. at 1374 (Stevens, J., concurring in the judgment) (concluding that the Avena judgment "constitutes an international law obligation" even though it "is not "the supreme Law of the Land"' (quoting U.S. CONST. art. VI, cl. 2)).

134. Id. at 1378 (Breyer, J., dissenting) (emphasis added); see also id. at 1390 (describing the majority as holding 'that the Nation's international legal obligation to enforce the ICJ's decision is not automatically a domestic legal obligation").

135. Id. at 1376 .

136. Sosa v. Alvarez-Machain, 542 U.S. 692, 760-61 (2004) (Breyer, J., concurring in part).

137. Id at 761 . One might argue that Justice Breyer thought this consideration peculiar to ATS litigation. But to reach this conclusion one would have to begin with the counterfactual pre- 
tion over claims by foreign nationals who are injured abroad by foreign conduct, Justice Breyer would consider whether there is a "procedural consensus" that the conduct in question warrants universal jurisdiction - that is, authorization for any state to exercise jurisdiction to prosecute the conduct. ${ }^{138}$ If such a consensus exists, then principles of comity are not threatened and adjudication of a CIL-based claim is appropriappropriate. ${ }^{139}$ The important point, however, is that Justice Breyer saw a more limited domestic role for CIL than did the Sosa majority, but he favored a broader role for treaties than did the majority in Medellin. Justice Breyer, at least, would seem to appreciate the revisionist position that CIL's domestic status should be more circumscribed than that of treaties because treaties are formally negotiated and approved by the political branches and are specifically included in the Supremacy Clause's catalogue of supreme federal law. ${ }^{140}$

\section{MEDELLÍN AND DEVELOPING UNIFORMITY FOR INTERNATIONAL LAW}

The Supreme Court's treatment of CIL in Sosa and treaties in Medellin likely results in a greater domestic role for treaties than for CIL. To the extent that uniform considerations, particularly political branch intent and specific definition, govern questions of both treaty selfexecution and CIL incorporation, treaties are likely to enjoy a broader role in the U.S. legal system than CIL. ${ }^{141}$ Treaties themselves provide evidence of the political branches' intent, and they contain written obligations that a court can evaluate for specific definition. ${ }^{142}$

Medellin supports the claim that a uniform doctrine governs the domestic status of both treaties and CIL. I previously argued, in light of Sosa's treatment of customary international law, that a doctrinal uniformity was emerging. ${ }^{143}$ That argument, however, relied on selfexecution considerations that were pieced together from Supreme Court

mise that the ATS was designed to limit federal judicial authority to hear CIL-based claims and proceed to assume that Justice Breyer was unwilling to consider the plaintiff's claim outside the confines of the ATS. See David H. Moore, Setting the Record Straight: Sosa v. Alvarez-Machain and the Debate over Customary International Law 10 (Am. Enter. Inst. for Pub. Policy Research, Working Paper No. 154, 2009), available at http:/www.aei.org/docLib/20090820-Chapter4.pdf.

138. Sosa, 542 U.S at 761-63 (Breyer, J., concurring in part).

139. Id. at 762 .

140. See Moore, supra note 4 , at 51 .

141. See id.

142. Id.

143. See id. 
and circuit court decisions. ${ }^{144}$ The Supreme Court had not previously provided extensive guidance on the content of the self-execution analysis. Medellin changed that: Medellin paints the fullest picture of the factors governing self-execution to date.

As the discussion above details, the primary consideration governing self-execution is the intent of the political branches. Specific definition, mutuality, practical consequences, foreign relations effects, and alternative means of enforcement contribute to the inquiry. A court is more likely to conclude that a treaty is self-executing if there is evidence that the political branches intended the treaty to be self-executing. That intent can be located in treaty text that imposes specifically defined obligations that reflect judicially enforceable standards. On the other hand, a treaty is less likely to be deemed self-executing if: (a) other states party to the treaty have not assumed a self-executing obligation; ${ }^{145}$ (b) the practical consequences of a self-executing classification are sweeping or otherwise give pause, ${ }^{146}$ (c) self-execution would produce untoward foreign affairs effects, including disruption of relations with other countries or constriction of the foreign affairs discretion of the political branches ${ }^{147}$ or (d) the treaty contemplates alternative means of enforcement. ${ }^{148}$

These factors parallel the considerations that the Supreme Court laid down in Sosa to guide the incorporation of norms of customary international law. As noted above, the Sosa Court focused on the intent of the political branches (specifically, the First Congress) to identify the source and scope of federal judicial authority to incorporate CIL norms. It sought norms of CIL that were specifically defined and well accepted by other states, unlike Alvarez-Machain's claim based on an abstract prohibition on arbitrary detention. The Court also considered the practical consequences and foreign relations effects of creating a CIL-based

144. Id. at $10-11$

145. See supra text accompanying notes 123-25 (highlighting the Medellin Court's observation that other states do not treat ICJ judgments as immediately enforceable in domestic courts).

- 146. See supra text accompanying notes 126-27 (noting the Medellin Court's apprehension that self-execution could give rise to unassailable ICJ judgments that preempt state and federal law and overturn criminal convictions).

147. See supra text accompanying notes 113-19 (discussing the Medellin Court's observation that self-execution would, inter alia, eliminate the political branches' discretion to decide "whether and how to comply with" ICJ judgments); supra text accompanying notes 120-22 (outlining the Medellin Court's concern that states would be hesitant to enter treaties if the judiciary possessed significant discretion to decide if and when treaties are self-executing).

148. See supra text accompanying notes 109-14 (discussing the Medellin Court's reliance on the contingent and political enforcement of ICJ judgments in the Security Council). 
cause of action, including opening the flood gates to alien claims based on unauthorized detention and eclipsing political branch authority over foreign affairs by creating problems with other states. Finally, the Sosa Court expressed willingness to consider alternative means of enforcement, such as exhaustion of local remedies.

The confluence of considerations in Medellin and Sosa not only reflects a consistent separation of powers vision, but also suggests that a uniform doctrine governing the domestic status of both treaties and CIL is not merely emerging but developing. ${ }^{149}$ Although the Supreme Court has yet to note this uniformity - the opinion in Medellin does not so much as cite Sosa-the parallels between the considerations governing treaty self-execution and CIL incorporation are apparent. Under this unifying doctrine, neither treaties nor customary international law will automatically qualify as enforceable domestic law, but treaties will be more likely to qualify than CIL. ${ }^{150}$

\section{CONCLUSION}

The Supreme Court's landmark decision in Medellin has predictably generated debate regarding its significance for the domestic role of treaties. Medellin's import, however, reaches farther than the literature has acknowledged. The decision diminishes prospects for ATS litigation based on violations of treaties by undercutting the number of treaties that may be judicially enforced at the behest of private individuals. The decision also limits ATS litigation based on breaches of CIL by reducing the number of treaties that may provide evidence of actionable CIL norms.

More significantly, Medellin's separation of powers vision lends support to the claim that the Supreme Court favors the revisionist view of customary international law. The revisionist view leaves the political branches to decide the extent to which the federal judiciary may rely on CIL as a rule of decision. The result is that Medellin directly limits the domestic role of treaties in U.S. courts and indirectly undermines reliance on CIL by the federal judiciary. Equally important, the decision evidences the development of a uniform doctrine governing the domestic status of both treaties and CIL-a doctrine under which the intent of the political branches, complemented by considerations of specificity, mutuality, practical consequences, foreign affairs effects, and alternative

149. See Moore, supra note 4.

150. See id. at 51 . 
means of enforcement, informs the domestic legal status of both sources of international law. 